\title{
$\mathrm{Cr}$ 강의 미세조직과 파괴인성에 미치는 열간단조 및 열처리 공정의 영향 \\ 이동준 ${ }^{1 * *} \cdot$ 권용남 ${ }^{1} \cdot$ 김민석 ${ }^{1} \cdot$ 구가은 $^{1} \cdot$ 허상현 ${ }^{2}$ · 김남용 ${ }^{2} \cdot$ 이진모 $^{2}$ \\ 1재료연구소 소재성형연구실 \\ 2(주)태웅 기업부설연구소
}

\section{Effect of Hot Forging and Heat Treatment on the Microstructure and Mechanical Properties of $\mathrm{Cr}$ Steel}

\author{
Dong Jun Lee ${ }^{1, *}$, Yong-Nam Kwon ${ }^{1}$, Min Suk Kim ${ }^{1}$, Ga Eun Ku${ }^{1}$, \\ Sang Hyun $\mathrm{Heo}^{2}$, Nam Yong Kim², and Jin-Mo Lee ${ }^{2}$ \\ ${ }^{1}$ Materials Deformation Department, Korea Institute of Materials Science (KIMS), Changwon 51508, Republic of Korea \\ ${ }^{2}$ Research Institute Attached, Taewoong, Busan 46751, Republic of Korea
}

\begin{abstract}
In this study, the effects of hot forging and heat treatment (quenching and tempering) of cast $\mathrm{Cr}$ alloy steel on the microstructures and mechanical properties were investigated. The hot forging was performed at a compressive ratio 0.5 at $1,250^{\circ} \mathrm{C}$. The heat treatment process was quenching $\left(860{ }^{\circ} \mathrm{C}\right.$ for 2 hours and water quenching) and tempering $\left(655{ }^{\circ} \mathrm{C}\right.$ for 2 hours and air cooling). The microstructures of the hot forged specimen showed bainite, pearlite and ferrite mixed phases with high tensile strength, but showed low fracture toughness. The heat treated specimens after hot forging showed tempered martensite microstructure and high fracture toughness but relatively low yield and tensile strengths. After tensile and fracture toughness tests, the cast and the hot forged specimens both showed cleavage fracture surfaces, which occurred between lamellar structures. However, the heat treated specimen had a ductile fracture surface with dimple shaped fractures. From these results, we could conclude that the high fracture toughness was caused not by the cleavage fracture mode in the pearlite and bainite phases, but delayed fracture due to a ductile fracture mode in the tempered martensite phase.
\end{abstract}

(Received September 11, 2017; Accepted December 27, 2017)

Keywords: Cr steel, heat treatment, fracture toughness, microstructure, tempered martensite

\section{1. 서 론}

$\mathrm{Cr}$ 강은 탄소농도가 $0.3 \sim 0.5 \%, \mathrm{Cr}$ 이 $0.8 \sim 1.2 \%$ 를 함유하 여 높은 강도와 좋은 인성을 나타내는 강으로 주로 절삭공 구나 자동차 부품, 베어링, 샤프트 등에 구조용 재료로 사 용되고 있다. 뿐만 아니라, $\mathrm{Mo}$ 나 $\mathrm{Ni}$ 을 첨가하여 $\mathrm{Cr}-\mathrm{Mo}$ 강 이나, Cr-Mo-Ni강으로 제조하여, 높은 내식성과 강도가 요 구되는 부품에 사용되고 있다.

이러한 합금강은 담금질(Quenching)과 뜨임(Tempering) 과정을 거치면서 미세조직의 변화에 따라 기계적 특성이 달라지게 된다. 많은 연구자들이 다양한 합금에 대하여 오

*Corresponding Author: Dong Jun Lee

[Tel: +82-55-280-3839, E-mail: djlee@kims.re.kr]

Copyright (C) The Korean Institute of Metals and Materials
스테나이트 열처리온도[1-5], 뜨임온도[6-9], 냉각속도[1012] 등을 달리하여 미세조직 변화와 이에 따른 기계적 특 성의 변화에 대하여 분석하였다. 또한 열기계적 공정[1216]을 추가하거나, 열처리 조건[17-19]을 다양하게 조절하 여 이에 따라 변화하는 미세조직과 인장, 충격, 피로 특성 을 분석하였다.

특히 압력용기용 강인 $\mathrm{A} 533 \mathrm{~B}$ 에 대하여 열처리 온도에 따 른 파괴인성 측정 결과를 보면, 베이나이트에서 마르텐사이 트 분율이 커질수록 파괴인성이 높아지는 것으로 나타났고 [1-3], 뜨임온도가 높아질수록 탄화물의 크기가 커지고 딤플 사이즈도 커져 이에 따라 강도는 줄어드는 결과가 보고되고 있다 $[5,6] . \mathrm{Cr}$ 스틸의 경우는 공형압연 후 생성된 lath 마르 텐사이트의 균열전파특성 및 충격인성을 연구한 논문도 보 고되고 있다 [14-16]. 이와 같이 다양한 공정변수를 바탕으 
로 그 특성의 변화에 대하여 많은 연구가 이루어 지고 있다.

본 연구에서는 주조된 $\mathrm{Cr}$ 강의 열간단조와 열처리 (quenching+tempering)공정에 따른 미세조직의 변화와 이 에 따른 기계적 특성의 변화에 대하여 연구하였다. 특히, 각 공정별로 파괴인성 시험을 실시하여, 파괴인성에 미치 는 미세조직의 영향에 대하여 분석하였다.

\section{실험방법}

본 실험에 사용된 소재는 표 1 의 조성을 가지는 $\mathrm{Cr}$ 강으 로, (주)한국진공야금에서 너비 $470 \mathrm{~mm}$, 폭 $90 \mathrm{~mm}$, 높이 $490 \mathrm{~mm}$ 의 크기로 주조하였다. 주조된 시편의 중심부에서 높이 방향으로 지름 $80 \mathrm{~mm}$ 높이 $140 \mathrm{~mm}$ 의 원통형 형 상의 시편으로 가공을 하여, $1,250{ }^{\circ} \mathrm{C}$ 의 온도에서 압하율 $50 \%$ 로 열간단조하여 공랭하였다. 열처리 조건은 $860{ }^{\circ} \mathrm{C}$ 에 서 2시간 유지 후 수냉하여 담금질 한 후 $655^{\circ} \mathrm{C}$ 에서 두 시간 뜨임 후 공랭하였다.

단조 및 열처리 공정을 거친 후의 미세조직 분석을 위하 여 광학현미경과 주사전자현미경(Scanning electron microscope, SU6600)을 통하여 기공을 관찰하였고, $2 \%$ nital 용액을 이용하여 에칭한 후 미세조직을 관찰하였다. 또 한 주사전자현미경의 $\mathrm{EBSD}(\mathrm{Electron}$ backscatter diffraction) 분석법을 이용하여 미세조직을 측정하였다. 기계 적 특성을 분석하기 위해 인장시험과 파괴인성 시험을 실시 하였다. 인장시험편은 단조 및 열처리 시편 크기의 한계로 인하여, ASTM E8에서 규정한 substandard 크기의 절반 크 기인 표점거리(gauge length) $12.5 \mathrm{~mm}$, 총 길이(total length) $50 \mathrm{~mm}$ 의 판상인장시편을 준비하여, 만능재료시험기 (Universal Testing Machine, UNITECH)에서 변형률 속도 $10^{-3} / \mathrm{s}$ 의 속도로 세 번 실시하였다. 파괴인성시험은 너비 $(\mathrm{W})$ $25.4 \mathrm{~mm}$, 두께(B) $12.7 \mathrm{~mm}$ 의 $\mathrm{C}(\mathrm{t})($ Compact tension) 시편 으로 준비한 뒤 ASTM E399와 ASTM E1820규격에 준하 여 유압식피로시험기(MTS Landmark)에서 파괴인성시험을 실시하여 비교하였다. 또한 인장시험과 파괴인성시험 후 파 단면 분석을 주사전자현미경으로 분석하였다.

\section{결과 및 고찰}

주조된 시편은 일반적으로 내부에 기공을 포함하는 경우
가 많은데, 본 실험에서 주조한 시편에서도 기공이 관찰되 었다. 그림 1 의 (a)를 보면 주조된 시편의 내부에 수 $\mu \mathrm{m}$ 에서 수백 $\mu \mathrm{m}$ 의 크기를 가지는 기공들이 존재하는 것으로 나타났다. 열간단조를 한 시편의 경우에서도(그림 $1 \mathrm{~b}$ ) 시 편 전체에 걸쳐 고르게 기공들이 존재하는 것으로 나타났 는데, 열처리 후 시편의 기공을 관찰해보면(그림 $1 \mathrm{c}$ ), 단조 후 시편보다 기공의 크기가 전체적으로 커지고, 분산도는 줄어든 것으로 나타났다. 이는 주조 후 수백 $\mu \mathrm{m}$ 의 기공들 이 열간단조 과정에서 파괴되어 미세하게 분산된 것으로 볼 수 있다. 이러한 기공들이 열처리 공정을 거치면서 주 변의 기공들끼리 뭉쳐 기공의 분산도는 줄어들고 크기는 커진 것으로 판단된다. 단조와 열처리 공정을 거치면서 내 부 기공률의 변화를 관찰하기 위하여 아르키메데스 원리를 이용하여 밀도를 측정한 결과 모두 세 시편 모두 $99.6 \%$ 의 밀도로 나타나 기공률의 변화는 없는 것으로 나타났다.

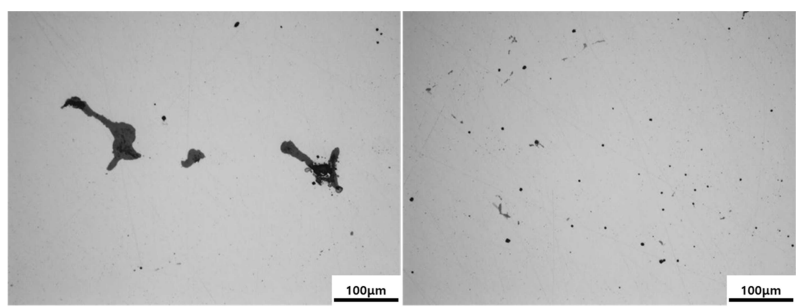

(a)

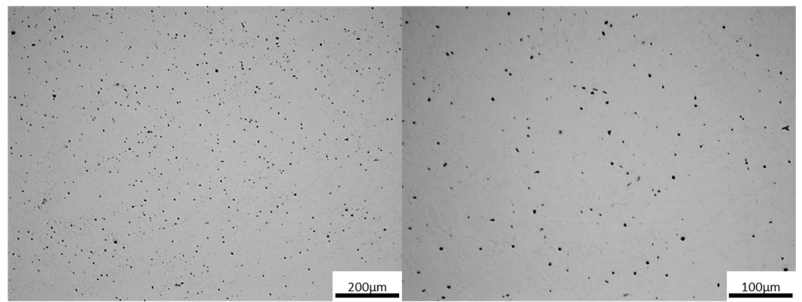

(b)

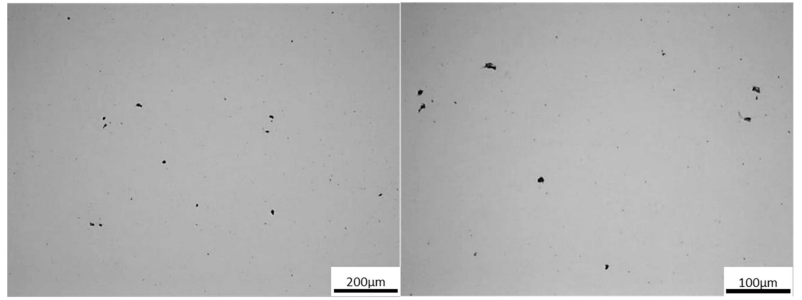

(c)

Fig. 1. Shapes and distributions of pores in the (a) casted, (b) forged and $(\mathrm{c})$ heat treated specimens.

Table 1. The chemical composition of $\mathrm{Cr}$ steel.

\begin{tabular}{c|c|c|c|c|c|c|c|c}
\hline Element & $\mathrm{Fe}$ & $\mathrm{C}$ & $\mathrm{Cr}$ & $\mathrm{Si}$ & $\mathrm{Mn}$ & $\mathrm{Al}$ & $\mathrm{Ti}$ & $\mathrm{V}$ \\
\hline $\operatorname{wt}(\%)$ & $\mathrm{Bal}$ & 0.3600 & 1.1090 & 0.3170 & 0.8737 & 0.0085 & 0.0172 & 0.0564 \\
\hline
\end{tabular}



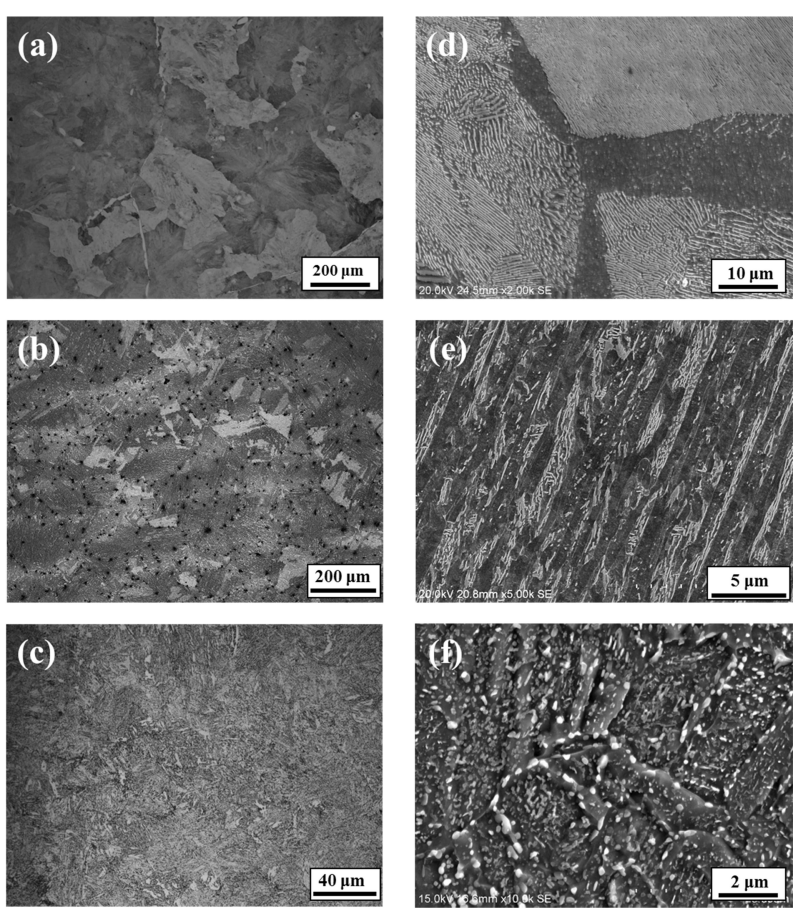

Fig. 2. (a-c) Optical microscopy and (d-f) Scanning electron microscope images for the microstructures of $(a, d)$ casted, $(b, e)$ forged and $(\mathrm{c}, \mathrm{f})$ heat treated specimens.

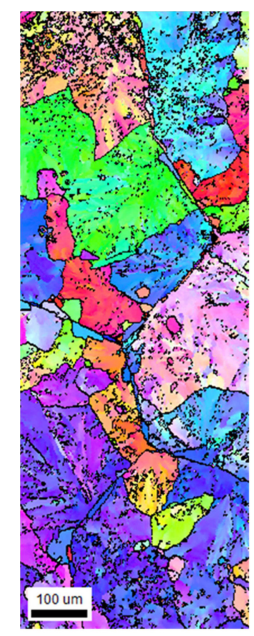

(a)

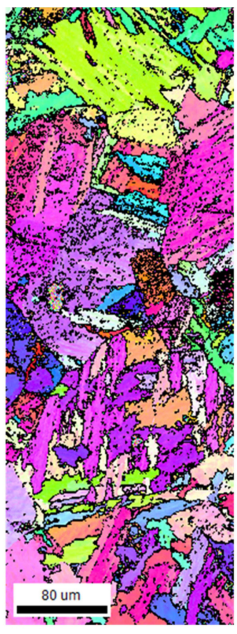

(b)

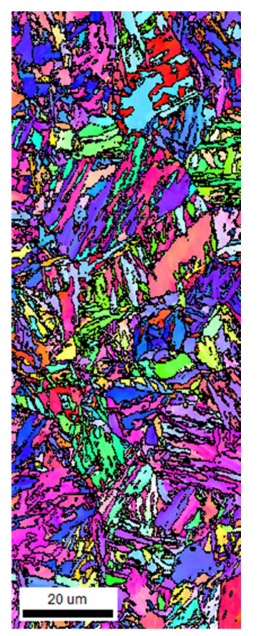

(c)
Fig. 3. Electron backscatter diffraction(EBSD) micrographs of (a) casted, (b) forged and (c) heat treated specimens.
주조된 시편의 미세조직은 그림 $2 \mathrm{a}, 2 \mathrm{~d}$ 에서 볼 수 있듯 이 펄라이트(pearlite)와 페라이트(ferrite)의 혼합상을 가지 며, 그림 $3 \mathrm{a}$ 의 $\mathrm{EBSD}$ 결과를 바탕으로 면적가중 평균결정 립도를 계산하면 $131 \mu \mathrm{m}( \pm 75 \mu \mathrm{m})$ 를 가지는 것으로 나 타났다. 이 결정립도 계산은 $\mathrm{EBSD}$ 측정면적에 비해 결정 립 수가 부족하여 측정값의 신뢰도는 떨어진다고 볼 수 있 으나, 이러한 결과를 통하여 주조된 시편은 수백 $\mu \mathrm{m}$ 의 결 정립도를 가지는 것으로 분석할 수 있다. 그림 $2 \mathrm{~b}$ 와 $2 \mathrm{e}$ 의 열간단조 후 시편은 lath 형태의 베이나이트(bainite)와 페 라이트의 혼합상으로 나타났다. 이 시편의 평균결정립도는 $68 \mu \mathrm{m}( \pm 48 \mu \mathrm{m})$ 로 이 또한 신뢰할 수 없는 값이나 수 십 $\mu \mathrm{m}$ 의 결정립 크기인 것을 확인할 수 있다. 이는 높은 단조온도에 따른 오스테나이트 결정립 크기의 증가로 인한 결과라 할 수 있다 [1]. 열처리 후 미세조직은 그림 $2 \mathrm{c}$ 와 $2 \mathrm{f}$ 에서 볼 수 있듯이, 템퍼트 마르텐사이트(tempered martensite)조직을 가지는 것을 확인할 수 있는데, 이는 $\mathrm{Ac} 3$ 온도 이상인 $860{ }^{\circ} \mathrm{C}$ 에서 수냉하여 얻은 마르텐사이 트 조직에서 $680^{\circ} \mathrm{C}$ 에서 템퍼링을 하면, 마르텐사이트 조 직내에 과포화 되어있는 탄소가 시멘타이트(cementite, $\mathrm{Fe}_{3} \mathrm{C}$ )와 같은 탄화물로 석출되어 미세한 석출상이 페라이 트 조직 내에 존재하는 템퍼트 마르텐사이트 조직을 형성 하게 된다.

인장시험을 통해 기계적 특성을 분석해 보면 그림 4와 표 2에서 나타난 바와 같이 주조, 단조, 열처리공정 후 항 복강도는 $468.8 \mathrm{MPa}, 756.9 \mathrm{MPa}, 726.3 \mathrm{MPa}$, 최대인장강 도는 $600.3 \mathrm{MPa}, 1000.6 \mathrm{MPa}, 845.6 \mathrm{MPa}$ 로 단조 후 시 편이 가장 높은 항복강도와 최대인장강도 값을 보였고, 연 신률은 열처리 후 시편에서 가장 높은 값을 나타냈다. 각 시편의 인장파단면을 주사전자현미경을 통해 관찰해 보면, 그림 $5 \mathrm{a}$ 에서 볼 수 있듯이 주조된 시편에서는 넓은 크기 를 가지는 기공에서부터 파괴가 시작되어 벽개(cleavage)파 괴 형상의 입내(transgranular)파괴현상을 보였다. 단조 후 시편의 경우에서도(그림 $5 \mathrm{~b}$ ) 벽개파면이 관찰되었는데, 두 소재 모두 펄라이트와 베이나이트 위주의 미세조직을 가지 고 있어, 페라이트와 시멘타이트의 층판(lamellar) 구조에서 시멘타이트의 미세크랙의 생성과 전파에 의해 파단이 일어

Table 2. The results of tensile tests.

\begin{tabular}{c|c|c|c|c|c|c}
\hline & $\begin{array}{c}\text { Yield Strength } \\
(\mathrm{MPa})\end{array}$ & $\begin{array}{c}\text { Error } \\
( \pm)\end{array}$ & $\begin{array}{c}\text { Tensile Strength } \\
(\mathrm{MPa})\end{array}$ & $\begin{array}{c}\text { Error } \\
( \pm)\end{array}$ & $\begin{array}{c}\text { Elongation } \\
(\%)\end{array}$ & $\begin{array}{c}\text { Error } \\
( \pm)\end{array}$ \\
\hline As-cast & 468.8 & 9.8 & 600.3 & 41.2 & 1.9 & 0.6 \\
\hline Forging & 756.9 & 14.2 & 1000.6 & 11.3 & 8.0 & 1.4 \\
\hline Forging+Heat treatment & 726.3 & 1.3 & 845.6 & 2.5 & 19.3 & 1.1 \\
\hline
\end{tabular}




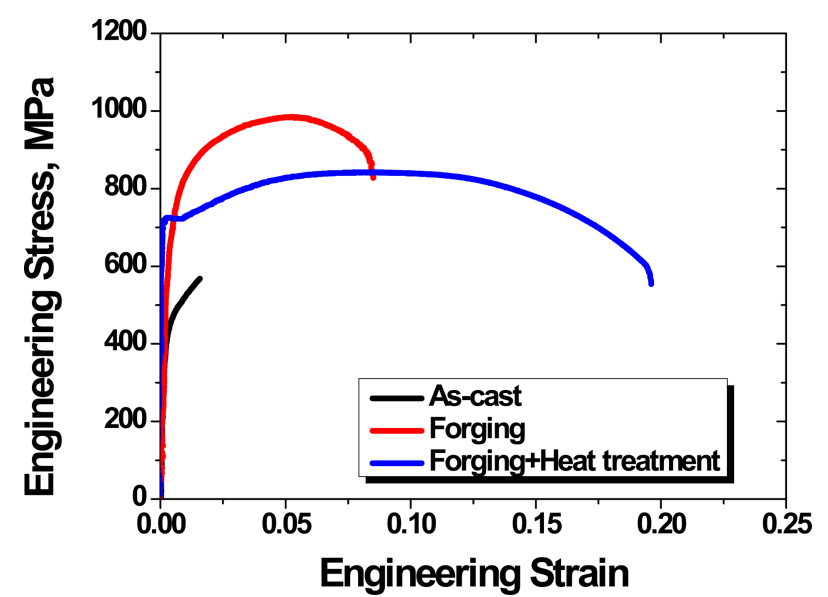

Fig. 4. The results of tensile tests of the samples after as-cast, forging and heat treatment.
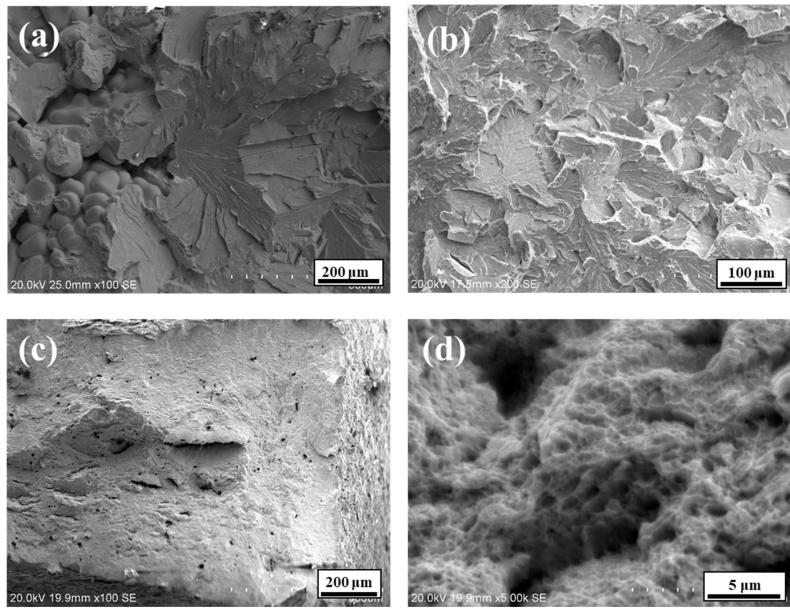

Fig. 5. SEM fractographs of (a) casted, (b) forged and (c) heat treated specimens after tensile tests. (d) Dimple shape fracture in the heat treated specimen.

나는 것으로 판단된다. 반면, 열처리 후 시편의 경우 앞서 연신률에서도 가장 높은 값을 나타낸 바와 같이 파단면을 관찰한 결과에서도 앞선 두 시편과 다른 양상을 보였다(그 림 5c). 열처리 시편에서는 전체적으로 미세한 딤플들이 이 루는 연성파괴가 이루어진 것을 알 수 있다(그림 $5 \mathrm{~d})$. 이 는 앞선 페라이트와 시멘타이트가 층판(lamellar)구조를 이 루는 것이 아니라, 시멘타이트가 페라이트 내에 미세하게 석출되어 있으므로, 페라이트의 변형률이 증가함에 따라 시 멘타이트의 크랙이 발생하지 않고, 내부의 기공(void)의 생 성에 의한 입계파괴(Intergranular)가 발생하는 것으로 판단 된다 $[1,6,8,17]$.

이러한 파괴현상의 차이는 파괴인성 시험에서 더욱 높은 차이를 나타냈다. 그림 $6 \mathrm{a}$ 에서 볼 수 있듯이 주조시편과

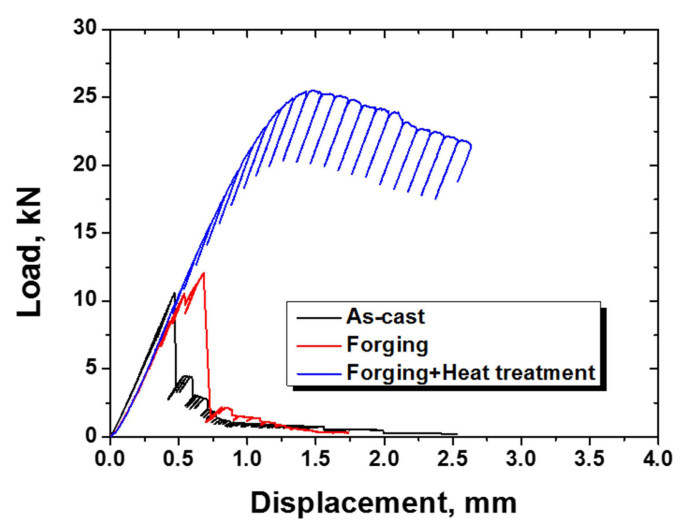

(a)

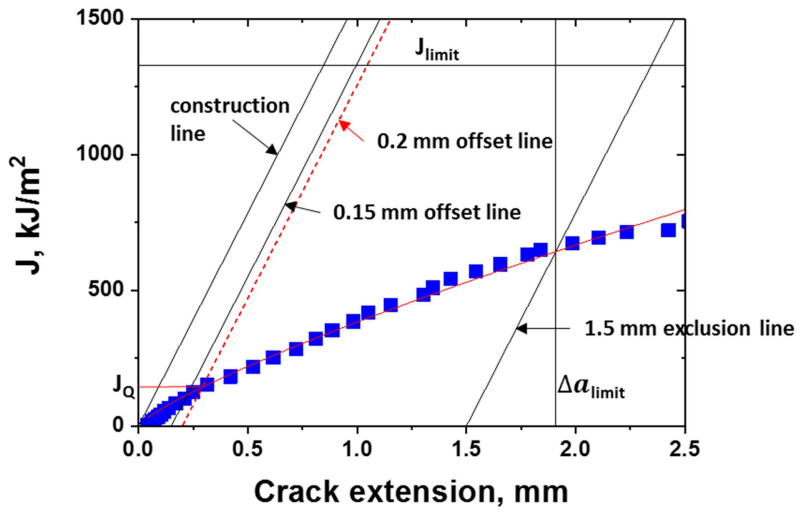

(b)

Fig. 6. Results of fracture toughness tests. (a) Load-displacement curves of casted, forged and heat treated specimens. (b) Analysis of fracture toughness test for heat treated specimen.

단조시편의 경우는 ASTM E1820을 통한 파괴인성 시험을 실시하기 어려울 정도로 크랙의 진전이 빠르게 이루어 졌 고, 열처리 시편의 경우에서는 J-integral 시험을 통해 $\mathrm{J}_{\mathrm{IC}}$ 값이 $154.12 \mathrm{~kJ} / \mathrm{m}^{2}$ 로 측정되었다. 비교를 위하여 각 시편 에 대하여 ASTM E399에 따라 평면변형파괴인성 $\left(\mathrm{K}_{\mathrm{IC}}\right)$ 시 험을 실시하여 $\mathrm{K}_{\mathrm{Q}}$ 값을 구해보면 주조시편, 단조시편, 열처 리시편에서 각각 $35.17 \mathrm{MPa} \sqrt{\mathrm{m}}, 43.51 \mathrm{MPa} \sqrt{\mathrm{m}}, 77.26$ $\mathrm{MPa} \sqrt{\mathrm{m}}$ 로, 열처리 시편에서 가장 높은 값을 보였다. 하지 만, 모든 평면변형파괴인성 시험에서 ASTM E399의 규정 인 $\mathrm{K}_{\max } / \mathrm{K}_{\mathrm{Q}}<1.1$ 을 만족하지 못하였으므로, $\mathrm{K}_{\mathrm{Q}}=\mathrm{K}_{\mathrm{IC}}$ 가 성 립되지 않아 평면변형파괴인성 값을 정의할 수는 없으나, $\mathrm{J}_{\mathrm{IC}}$ 시험의 어려움으로 측정이 힘든 주조재와 단조재의 파 괴인성 값을 어느정도 측정할 수 있었다. 이러한 파괴인성 차이를 확인하기 위하여 파단면 분석을 실시하였다. 그림 7 에서 볼 수 있듯이, 조기 파단이 발생한 단조 시편에서는 앞선 인장시험 파단면 분석에서 본 바와 같이 벽개파괴의 표면을 관찰 할 수 있었고, 열처리 시편에서는 예비피로균 


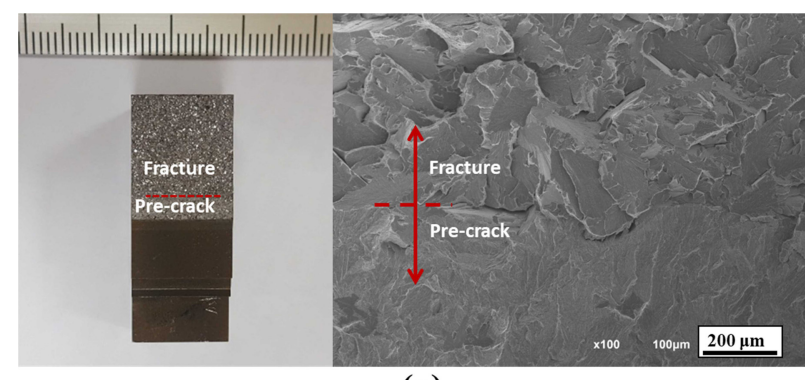

(a)

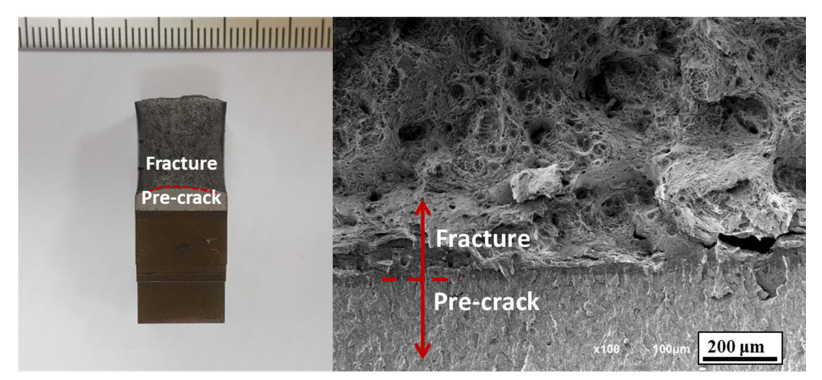

(b)

Fig. 7. SEM fractographs of (a) forged and (b) heat treated specimens after fracture toughness tests.

열 이후 딤플형태의 파단면이 관찰되는 연성파괴가 발생하 고, 시편 옆 표면에서부터 소성변형이 발생하면서 파괴에 대한 저항성을 보이는 것으로 나타났다.

주조재와 단조재처럼 펄라이트, 베이나이트에서 발생하 는 벽개파괴 현상은 Zhang and Knott[1] 연구에서 설명과 같이 다음과 같은 3 단계로 진행이 된다. 먼저 하중이 증가 함에 따라 페라이트에서 생성되어 움직인 전위에 의하여 시멘타이트에 응력집중을 발생하게 되어 시멘타이트에 미 세균열을 발생하게 된다. 이때, 파괴인성 시험에서 하중-변 위 그래프에서는 변위의 증가에 비례하여 하중이 증가하게 된다. 하중이 계속해서 증가하여 응력집중이 커지게 되면, 앞에서 발생한 미세균열이 전파되면서 베이나이트의 층판 (lath) 방향과 수직한 방향으로 조대균열이 생성이 된다. 이 러한 균열의 전파는 한 패킷(packet) 또는 여러 패킷에서 발생하게 되는데, 이때, 하중-변위 그래프에서는 하중의 급 격한 저하 후 다시 상승하는 팝인(pop-in) 현상이 발생한 다. 계속해서 하중이 증가하면, 이러한 균열의 전파가 지속 적으로 발생하여 시편의 파단이 발생하게 된다. 이러한 현 상을 바탕으로 주조재와 단조재의 파괴현상시험에서도 그 림 $6 \mathrm{a}$ 와 같이 팝인 현상이 발생한 후 파단이 발생하는 것 을 보였다. 하지만, 열처리 시편의 파괴거동은 시멘타이트 의 미세균열에 의한 전파가 아닌 페라이트의 변형률 증가 에 따른 기공의 생성-성장 거동에 의한 연성파괴가 발생하
므로, 높은 파괴인성값을 보이게 된다.

$\mathrm{Cr}$ 강의 경우 대부분의 경우 수냉(또는 유냉)과 템퍼링 공 정을 거친 후 사용되는데, 이는 강도를 감소시키는 대신 파괴인성을 증가시키기 위함이다. 앞선 실험결과들을 살펴 보면, 주조 후 시편과 단조 후 시편의 항복강도, 인장강 도, 연신률을 비교하였을 때, 단조 후 모든 부분에서 그 값이 증가하였으나, 파괴인성 시험에서 최대 하중이나 $\mathrm{K}_{\mathrm{IC}}$ 시험에서 얻은 $\mathrm{K}_{\mathrm{Q}}$ 값의 차이는 크기 않았다. 반면 열처리 후 시편의 경우는 단조 후 시편과 비교하였을 때 연신률에 서 높은 값을 보이나, 항복강도나 인장강도는 낮은 값을 보였다. 하지만, 파괴인성값은 유난히 높은 값을 보이고, 파 괴지연에 대한 특성 또한 좋았다.

중탄소강의 공형압연 온도에 따른 특성변화를 분석한 $\mathrm{Jia}$ and etc.[13]의 연구결과에서도 공형압연 온도에 따라 충격 특성이 달라졌는데, 특히, 인장시험에서는 항복강도, 인장 강도, 연신률에서는 큰 차이가 없었으나, 충격시험에서 흡 수에너지의 차이는 두 배 가까이 나타났다. 이는 시멘타이 트의 형태가 구형(spheroidal)인지, 층상형태인지가 중요한 인자로 작용하였다. 이러한 결과를 종합해보면, $\mathrm{Cr}$ 강의 파 괴인성은 열처리에 따라 시멘타이트의 형상이 펄라이트와 베이나이트와 같이 특정방향성을 따라 성장을 하였는지, 미세한 입자형태로 분산되어 있는지에 따라 파괴특성이 달 라진다. 특히, 층상구조의 형태에서는 인장강도가 증가하는 것으로 나타났으나, 파괴인성시험에서는 시멘타이트에서 생 성된 미세크랙들로 인하여 파괴저항상이 낮아져, 파괴인성 의 현저한 저하를 보였다. 하지만 시멘타이트가 석출되어 미세하게 분산되어 있는 미세조직에서는 인장강도의 저하 가 발생하였으나, 파괴인성시험에서 미세균열의 부재에 따 른 균열전파에 대한 지연효과가 발생하여, 파괴인성의 향 상을 꾀할 수 있었다.

\section{4. 결 론}

본 연구에서는 $\mathrm{Cr}$ 강을 주조 후 $1,250^{\circ} \mathrm{C}$ 의 온도에서 압 하율 $50 \%$ 로 열간단조를 실시한 후 $860^{\circ} \mathrm{C}$ 에서 2 시간 열 처리 후 수냉한 뒤, $655^{\circ} \mathrm{C}$ 에서 두 시간동안 뜨임공정을 수행하였다. 각 공정 후 미세조직변화와 인장시험과 파괴 인성시험을 실시하여, 공정과 미세조직이 기계적특성에 미 치는 영향에 대하여 분석하였다.

1. 조대한 펄라이트 조직과 큰 기공을 가지는 주조재를 열간단조를 수행하게 되면, 기공은 미세하게 분산되고 베 이나이트 조직을 가지게 되며, 열처리를 거치면서 탄화물 들이 석출된 템퍼트마르텐사이트 조직을 나타냈다. 
2. 주조재의 경우 내부의 기공들 같은 주조결함들로 인하 여, 낮은 강도와 적은 연신률을 보이는 반면, 베이나이트 조직을 가지는 열간단조재에서 가장 높은 항복강도와 인장 강도를 보였다. 하지만 연신률은 열처리 후 시편에서 가장 높은 값을 보였으며, 이는 펄라이트, 베이나이트 조직에서 나타나는 벽개파괴와는 달리 템퍼트 마르텐사이트에서 나 타나는 연성파괴로 인한 연신률 증가라 할 수 있다.

3. 파괴인성 시험결과 템퍼트 마르텐사이트를 가지는 열 처리시편에서 가장 높은 파괴인성값을 나타냈으며, 이는 탄 화물의 모양에 따라 파괴모드가 차이 때문이다. 펄라이트, 베이나이트와 같이 시멘타이트가 페라이트 내에 층판형태 로 존재하게 되면 미세크랙이 시멘타이트에서 발생하게 되 어 균열 저항성이 떨어지는 반면, 템퍼드 마르텐사이트와 같이 미세하게 분산된 탄화물을 가지는 미세조직의 경우는 기지상의 변형에 따른 파괴지연효과에 의하여 파괴인성이 높아지는 것으로 분석되었다.

\section{감사의 글}

본 연구는 신재생에너지기술개발사업의 지원으로 수행되 었습니다.

\section{REFERENCES}

1. X. Z. Zhang and J. F. Knott, Acta Mater. 47, 3483 (1999).

2. P. Bowen, S. G. Druce, and J. F. Knott, Acta Metall. 34, 1121 (1986).

3. P. Bowen, S. G. Druce, and J. F. Knott, Acta Metall. 35, 1735 (1987).

4. S.-Y. Lee, S.-I. Lee, and B. Hwang, Korean J. Met. Mater.
54, 637 (2016).

5. T. S. Wang, J. Yang, C. J. Shang, X. Y. Li, B. Zhang, and F. C. Zhang, Scripta Mater. 61, 434 (2009).

6. A. Salemi and A. Abdollah-zadeh, Mater. Charact. 59, 484 (2008).

7. W. S. Lee and T. T. Su, Mater. Proc. Tech. 87, 198 (1999).

8. E. K. Tschegg and S. Suresh, Metall. Trans. A 19, 3035 (1988).

9. J. J. Hoyos, H. R. Salva, J. M. Vélez, and A. A. Ghilarducci, Mater. Sci. Eng. A 660, 148 (2016).

10. K.-H. Lee, S.-G. Park, M.-C. Kim, and B.-S. Lee, Mater. Sci. Eng. A 534, 75 (2012).

11. G.-H. Kim, J.-H. Jang, S.-H. Kim, B.-J. Kim, K.-Y. Sohn, and D.-G. Nam, Korean J. Met. Mater. 55, 559 (2017).

12. S. Sankaran, V. Subramany Sarma, K. A. Padmanabhan, G. Jaeger, and A. Koethe, Mater. Sci. Eng. A 362, 249 (2003).

13. N. N. Jia, K. Guo, Y. M. He, Y. H. Wang, J. G. Peng, and T. S. Wang, Mater. Sci. Eng. A 700, 175 (2017).

14. C. Wang, H. Qiu, Y. Kimura, and T. Inoue, Mater. Sci. Eng. A 669, 48 (2016).

15. Y. Kimura, T. Inoue, F. Yin, and K. Tsuzaki, ISIJ International 50, 152 (2010).

16. T. Inoue, Y. Kimura, and S. Ochiai, Scripta Mater. 65, 552 (2011).

17. A. Abdollah-Zadeh, A. Salemi, and H. Assadi, Mater. Sci. Eng. A 483-484, 325 (2008).

18. E. Paravicini Bagliani, M. J. Santofimia, L. Zhao, J. Sietsma, and E. Anelli, Mater. Sci. Eng. A 559, 486 (2013).

19. J. Feng, T. Frankenbach, and M. Wettlaufer, Mater. Sci. Eng. A 683, 110 (2017). 